\title{
PENGARUH SISTEM FERTIGASI DENGAN PUPUK ORGANIK CAIR LIMBAH IKAN PADA PERTUMBUHAN TANAMAN CABAI (Capsicum annum. L)
}

\author{
Oleh : \\ Ramli*) \\ Nurdi Ibnu Wibowo**) \\ Adi Ilman Bissalam***)

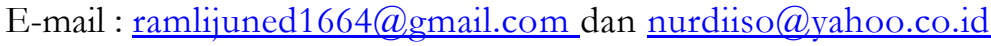

\begin{abstract}
Abstrak
Pemberian nutrisi terhadap tanaman merupakan suatu usaha yang bertujuan untuk meningkatkan hasil produksi yang diinginkan. Penelitian ini bertujuan untuk mengetahui pengaruh konsentrasi pupuk cair limbah ikan dengan sistem fertigasi terhadap pertumbuhan vegetatif tanaman cabai (Capsicum annum $L$ ). Penelitian ini dilaksanankan pada bulan April sampai dengan bulan Juli 2020, menggunakan rancangan acak lengkap (RAL) dengan 1 faktor perlakuan yaitu pemberian konsentrasi pupuk cair limbah ikan. Faktor I: konsentrasi pupuk cair limbah ikan: F0 $=0 \mathrm{ml} /$ liter F1 $=1 \mathrm{ml} /$ liter F2 $=5 \mathrm{ml} /$ liter F3 $=10 \mathrm{ml} /$ liter F4 = $15 \mathrm{ml} /$ liter. Hasil penelitian ini menunjukkan konsentrasi pupuk cair limbah ikan tidak berpengaruh nyata, perlakuan terbaik pemberian pupuk cair limbah ikan ini yaitu F2 = $5 \mathrm{ml} /$ liter.
\end{abstract}

Kata kunci: Interaksi, Konsentrasi, Fertigasi, Pupuk Cair Limbah Ikan, Cabai.

\begin{abstract}
Providing nutrition to plants is an effort that aims to increase the desired production results. This study aims to determine the effect of the concentration of fish waste liquid fertilizer with the fertigation system on the vegetative growth of chili (Capsicum annum L). This research was conducted from April to July 2020, using a completely randomized design (CRD) with 1 treatment factor, providing the concentration of fish waste liquid fertilizer. Factor I: fish waste liquid fertilizer concentration: FO =0 ml / liter F1 $=1 \mathrm{ml} /$ liter $\mathrm{F} 2=5 \mathrm{ml} /$ liter F3 $=10 \mathrm{ml} /$ liter F4 $=15 \mathrm{ml} /$ liter. The results of this study indicate that the concentration of fish waste liquid fertilizer has no significant effect, the best treatment of this fish waste liquid fertilizer is F2 $=5 \mathrm{ml} /$ liter.
\end{abstract}

Key words: Interaction, concentration, fertigation, fish waste liquid fertilizer, chili.

*) Dosen Fakultas Sains Terapan UNSUR.

**)Dosen Pusat Pengembangan dan Pemberdayaan Pendidik dan Tenaga Kependdidikan (PPPPTK Pertanian).

***) Alumni Fakultas Sains Terapan UNSUR. 


\section{PENDAHULUAN}

Cabai (Capsicum annum L.) adalah jenis cabai yang paling umum dibudidayakan di berbagai daerah Indonesia, jenis cabai ini memiliki rasa yang pedas dan terdapat juga memiliki rasa yang tidak pedas semuanya tergantung dari jenisnya. Di Indonesia cabai dapat memiliki harga yang tinggi menjadikan salah satu komoditas hortikultura yang dapat mensejahterakan petani.

Cabai memiliki berbagai macam masalah dalam budidayanya sehingga adanya perlakuan khusus (Sumarna, 1998). Tingginya suatu kelembaban di sekitar tanaman karena curah hujan dapat menyebabkan pesatnya perkembangan sebuah penyakit. Selain daripada itu, jika terjadinya hujan lebat maka banyaknya bunga dan bakal buah yang gugur serta busuk. Hal ini menyebabkan berkurangnya hasil yang optimal pada tanaman cabai.

Irigasi adalah usaha pemberian air untuk memberikan kecukupan air dan memberikan kelembaban lahan. Suatu kenyataan bahwa di Indonesia menjadikan air sebagai kebutuhan yang berharga maka dari itu perlu adanya upaya efisiensi dalam penggunaan air, salah satu sarana dalam penggunaan dan efisiensi air yaitu dengan sistem irigasi tetes. Ridwan (2013) mengatakan bahwa, irigasi tetes merupakan sebuah irigasi yang memiliki tekanan rendah dan debit kecil dengan sistim pemberian air tersebut diaplikasikan di sekitar perakaran tanaman melalui sistem penetes (emitter). Pada daerah yang memiliki curah hujan yang rendah tingkat kehilangan air dapat sangat tinggi yang dinamakan evaporasi, sistem irigasi memungkinkan pemberian air secara tepat dan terarah pada tanaman sehingga meminimalkan kehilangan air, Selain untuk efisiensi air irigasi tetes digunakan sebagai optimalisasi pemberian nutrisi secara tepat dan dapat menghemat biaya operasional.

Kebutuhan air pada setiap tanaman berbeda beda dari proses vegetative akan menentukan hasil dari tanaman tersebut, cabai (Capsicum annum. L) sebagai tanaman yang memiliki kebutuhna air yang perlu sekali untuk di perhatikan kebutuhan airnya yang nanti akan menentukan hasil dari tanaman cabai tersebut. Kebutuhan air tersebut, dapat ditentukan berdasarkan hitungan koefisien tanaman (kc) dan evapotranspirasi (ETo) (Supriadi, 2018). Sedangkan, evapotranspirasi referens itu dapat dihitung oleh koefisien panci $(\mathrm{Kp})$ dan evaporasi panci (Eo). Oleh karean itu, nilai koefisien pada yang tanaman berbeda-beda setiap fase tumbuh tanaman dan setiap tanaman.

Pupuk merupakan salah satu bahan tambahan yang dibutuhkan tanaman sebagai energi, tumbuh, dan berkembang, ketika tanaman tersebut kekurangan unsur hara. Berdasarkan jenisnya, pupuk dibagi menjadi 2 jenis yaitu pupuk organik dan pupuk non-organik. Pupuk Organik Cair (POC) merupakan salah satu jenis pupuk organik yang dalam penggunaanya menjadi alternative yang sangat baik untuk pertanian berkelanjutan (Hannisar. 2018). Keuntunagan dari pupuk organik yaitu dapat menyediakan unsur hara, mengatasi defisiensi unsur hara secara cepat dan tidak bermasalah dalam pencucian hara. 
Salah satu dari jenis pupuk organik cair adalah pupuk yang terbuat dari hewan hewan hidup atau hewan mati yang di fermentasikan menjadi pupuk cair, pupuk jenis ini di perlukan tanaman untuk memenuhi sintesis protein pada tanaman. Salah satu pupuk organik tersebut yaitu dapat memanfaatkan sisa-sisa ikan yang terbuang dengan memanfaatkannya sebagai bahan baku yang memiliki kandungan unsur-unsur makronya. Meskipun kandunganya terbatas (tidak mencukupi untuk kebutuhan tanaman) maka harus dilengkapi dengan penambahan unsur lainnya sehingga kandungan N, P, K nya sesuai yang dibutuhkan (Zahroh. 2018).

Menurut Sumarna (1998) teknik irigasi tetes dengan cara fertigasi pada tanaman cabai, pada pemberian pupuk dapat sejalan dengan fase pertumbuhan fisiologis tanaman dan pupuk akan terdapat di daerah rangkum akar sehingga perkembangan akar akan lebih cepat dan luas. Hal ini terbukti dengan jumlah buah dan bobot buah lebih tinggi dibanding non fertigasi atau budidaya tanaman cabai secara irigasi tetes dengan fertigasi.

Penelitian budidaya tanaman cabai dengan sistem irigasi tetes fertigasi dan penambahan konsentrasi pupuk organik cair limbah ikan belum pernah dilakukan, maka dari itu penelitian ini dapat memanfaatkan POC limbah ikan dan memberikan hasil buah cabai yang optimal.

\section{METODE PENELITIAN}

\section{Waktu dan Tempat}

Penelitian ini dilaksanakan selama 3 bulan yaitu pada bulan April sampai Juli 2020 di BTN Bumi Emas blok e1/14, Jalan Raya Sukabumi, Desa Sirnagalih, Kecamatan Cilaku, Kabupaten Cianjur.

\section{Alat dan Bahan}

Alat dan bahan yang digunakan penelitian ini yaitu: Selang PE diameter 13/100 m, T joint 10 pcs, Drip stick 25 pcs, Ember 5 pcs, Air, Polybag 25 pcs $25 \times 25 \mathrm{~cm}$, Tanah, 1 bungkus benih Cabai (Capsicum annum L,) ukuran 5 gram, 1 Pupuk organik cair limbah ikan dalam botol 1 liter, dan Pipet ukuran 5-10 mL.

\section{Jenis Penelitian}

Penelitian dilakukan untuk mengetahui pengaruh pertumbuhan (Tinggi tanaman, Jumlah daun) pada tanaman cabai (Capsicum annum L.) dengan melihat konsentrasi dari pupuk organik cair limbah ikan. Penelitian ini menggunakan Rancangan Acak Lengkap (RAL), yaitu penggunaan pupuk organik cair dalam konsentrasi sebagai berikut:

$$
\begin{array}{ll}
\text { F0 } & : 0 \mathrm{~mL} / \text { Liter } \\
\text { F1 } & : 1 \mathrm{~mL} / \text { Liter } \\
\text { F2 } & : 5 \mathrm{~mL} / \text { Liter } \\
\text { F3 } & : 10 \mathrm{~mL} / \text { Liter }
\end{array}
$$


F4 :15 mL/Liter

Jumlah perlakuan adalah 5 , masing-masing perlakuan diulang sebanyak 5 kali sehingga diperoleh 25 unit percobaan.

\section{Variabel Penelitian}

Variabel yang diteliti yaitu Tinggi tanaman dihitung mulai permukaan tanah tanaman dan diamati pada 2, 4, 6, 8 minggu setelah tanam dan dihitung secara menyeluruh pada minggu 8 , dihitung dengan satuan Centimeter $(\mathrm{cm})$.

Jumlah Daun (Helai), daun yang diamati pada 2, 4, 6, 8 minggu setelah tanam dan dihitung secara menyeluruh pada minggu 8 , dihitung jumlah helai daun dengan satuan bilangan.

\section{Teknik Analisis Data}

Teknis analisis data menggunakan software Microsoft Excel dan Minitab 18. Data yang diperoleh dalam penelitian ini menggunakan uji Analysis of Variance (ANOVA). Uji ANOVA dilakukan untuk mengetahui masing - masing variabel independen secara sendiri-sendiri apakah mempunyai pengaruh yang signifikan terhadap variabel dependen atau pun tidak mempunyai pengaruh sama sekali. Jika terdapat pengaruh perlakuan, dilakukan uji Tukey. tinggi, jumlah daun, menggunakan aplikasi Microsoft Excel 2007 dan Minitab 18.

\section{HASIL DAN PEMBAHASAN}

\section{Pengaruh Tinggi Tanaman terhadap Tanaman Cabai dengan Menggunakan Sistem Fertigasi}

Pada hasil uji ANOVA, tidak terdapat pengaruh yang signifikan disebabkan PValue lebih besar dibandingkan dengan taraf signifikan $(0,05)$.

Tabel 1. Rata rata tinggi tanaman cabai.

\begin{tabular}{lcccc}
\hline Perlakuan & Minggu ke 2 & Minggu Ke 4 & Minggu Ke 6 & Minggu Ke 8 \\
\hline Kontrol & $5,100 \mathrm{a}$ & $5,400 \mathrm{a}$ & $5,500 \mathrm{a}$ & $5,600 \mathrm{a}$ \\
$1 \mathrm{ml} / 1$ liter & $5,400 \mathrm{a}$ & $5,600 \mathrm{a}$ & $5,700 \mathrm{a}$ & $5,800 \mathrm{a}$ \\
$5 \mathrm{ml} / 1$ liter & $5,600 \mathrm{a}$ & $5,900 \mathrm{a}$ & $6,200 \mathrm{a}$ & $6,500 \mathrm{a}$ \\
$10 \mathrm{ml} / 1$ liter & $5,400 \mathrm{a}$ & $5,400 \mathrm{a}$ & $5,600 \mathrm{a}$ & $5,800 \mathrm{a}$ \\
$15 \mathrm{ml} / 1$ liter & $5,400 \mathrm{a}$ & $5,500 \mathrm{a}$ & $5,500 \mathrm{a}$ & $5,500 \mathrm{a}$ \\
\hline
\end{tabular}

Pada tabel di atas, dapat dijelaskan bahwa tidak terdapat pengaruh yang signifikan dari minggu kedua hingga minggu kedelapan. Perlakuan $5 \mathrm{ml} /$ liter merupakan perlakuan dengan hasil terbaik dari segi pertumbuhan tinggi tanaman tersebut dari kegiatan penelitian ini.

Pada pertumbuhan tinggi tanaman terdapat beberapa faktor yang mendukung optimalnya pertumbuhan tinggi tanaman yang paling umum adalah unsur hara $\mathrm{N}$ (Nitrogen). Menurut (Leiwakabesssy et al., 2003), bahwa nitrogen ini dapat berfungsi sebagai peningkatan pertumbuhan tanaman tetapi jumlah kebutuhanya harus seimbang agar tersedia bagi tanaman. Kondisi nitrogen yang optimum sangat penting 
dalam fase pertumbuhan tanaman terutama untuk pembentukan akar, batang dan daun dengan baik. Penggunaan nitrogen yang berlebihana pada fase pertumbuhan vegetatif dapat menyebabkan tanaman menjadi mudah terserang penyakit. Sedangkan kekurangan nitrogen juga membuat pertumbuhan tanaman tertekan dan daun-daun mengalami klorosis dan kering. Oleh karena itu, kebutuhan kandungan unsur hara $\mathrm{N}$ (Nitrogen) dengan kondisi yang optimum pada tanaman tersebut dapat membantu pembentukan tinggi batang yang optimum, sehingga untuk beberapa produk hasil pembuatan pupuk organik dapat dilakukan dengan baik yaitu memberikan kandungan unsur hara $\mathrm{N}$ (Nitrogen) yang optimal akan tetapi pada penelitian ini tidak menunjukkan hasil data yang signifikan dari pemberian pupuk organik cair limbah ikan.

Pada penelitian (Zahroh et al., 2018) pupuk yang terkandung dalam limbah ikan yang telah mengalami proses fermentasi mengandung $\mathrm{N}$-total sebanyak 0,30\%, Fosfor dalam bentuk $\mathrm{P}_{2} \mathrm{O}_{5}$ sebanyak $0,65 \%$, dan Kalium dalam bentuk $\mathrm{K}_{2} \mathrm{O}$ sebanyak $0,17 \%$. Unsur $\mathrm{N}, \mathrm{P}$, dan $\mathrm{K}$ ini tidak terlalu tinggi jika disesuaikan dengan standar mutu pupuk komersil oleh Permentan yaitu Peraturan Menteri Pertanian Nomor 70/Permentan/SR.140/10/2011 menyebutkan bahwa standar mutu pupuk organik cair adalah sebesar $3-6 \%$. Diduga ini merupakan penyebab dari tidak optimalnya pertumbuhan tinggi tanaman dan mendapatkan hasil data yang tidak signifikan.

Pada penerapan aplikasi di lapangan, penelitian ini menggunakan sistem fertigasi, yaitu pemberian nutrisi tanaman yang digabungkan dengan air sebagai kebutuhan dasar tanaman, pada penerapan di lapangan, pupuk organik cair limbah ikan di campurkan langsung pada penampungan atau tangki air dimaksudkan saat pemberian air dan nutrisi dapat bersamaan dalam satu waktu akan tetapi hal ini diduga memiliki kelemahan pada penerapannya, yaitu adanya pengendapan pupuk organik cair pada penampungan atau tangki air tersebut, hal ini diduga kekentalan pada pupuk organik tersebut cukup pekat dan seharusnya diukur terlebih dahulu dengan menggunakan alat viscometer, akan tetapi pada penelitian ini tidak diukur tingkat kekentalan dengan alat tersebut, sehingga pupuk tersebut mengendap pada dasar penampungan atau tangki air, sedangan lubang saluran air atau keran air berada $5 \mathrm{~cm}$ dari atas dasar penampungan.

Adapun pengaruh nilai $\mathrm{pH}$ pada tanah yang digunakan pada penelitian ini, hal ini menyebabkan tanaman menjadi tidak optimal, terlebih $\mathrm{pH}$ memiliki peran yang penting dalam penyerapan nutrisi pada tanaman, semakin asam $\mathrm{pH}$ tanah maka nutrisi yang terdapat pada pupuk sulit diserap oleh tanaman, diduga tanah yang digunakan memiliki $\mathrm{pH}$ tanah yang asam, akan tetapi penelitian ini tidak menguji $\mathrm{pH}$ tanah yang digunakan sebelum dan sesudah kegiatan penelitian ini berlangsung, hal yang sama terjadi jika tanah memiliki $\mathrm{pH}$ yang terlalu basa. 


\section{Pengaruh Jumlah Daun terhadap Tananaman Cabai dengan Menggunakan Sistem Fertigasi}

Pada hasil uji ANOVA, tidak terdapat pengaruh yang signifikan disebabkan PValue lebih besar dibandingkan dengan taraf signifikan $(0,05)$.

Tabel 2. Rata rata jumlah daun tanaman cabai.

\begin{tabular}{ccccc}
\hline Perlakuan & Minggu ke 2 & Minggu Ke 4 & Minggu Ke 6 & Minggu Ke 8 \\
\hline Kontrol & $2,600 \mathrm{a}$ & $3,000 \mathrm{a}$ & $3,200 \mathrm{a}$ & $3,600 \mathrm{a}$ \\
$1 \mathrm{ml} / 1$ liter & $2,400 \mathrm{a}$ & $3,000 \mathrm{a}$ & $3,400 \mathrm{a}$ & $4,200 \mathrm{a}$ \\
$5 \mathrm{ml} / 1$ liter & $2,400 \mathrm{a}$ & $3,000 \mathrm{a}$ & $3,400 \mathrm{a}$ & $3,800 \mathrm{a}$ \\
$10 \mathrm{ml} / 1$ liter & $2,600 \mathrm{a}$ & $3,200 \mathrm{a}$ & $3,200 \mathrm{a}$ & $4,000 \mathrm{a}$ \\
$15 \mathrm{ml} / 1$ liter & $2,800 \mathrm{a}$ & $2,800 \mathrm{a}$ & $3,000 \mathrm{a}$ & $3,800 \mathrm{a}$
\end{tabular}

Pada tabel di atas, dapat dijelaskan bahwa tidak terdapat pengaruh yang signifikan dari minggu kedua hingga minggu kedelapan. Perlakuan $10 \mathrm{ml} /$ liter merupakan perlakuan dengan hasil terbaik pada penelitian ini

Adapun pengaruh suhu menjadi salah satu faktor mengapa penelitian ini tidak menjukan data yang signifikan, merupakan salah satu syarat tumbuh tanaman cabai. Suhu berpengaruh pada pertumbuhan tanaman, demikian juga terhadap tanaman cabai. Suhu yang ideal untuk budidaya cabai adalah $24-28{ }^{\circ} \mathrm{C}$. Pada suhu tertentu seperti kurang dari $15{ }^{\circ} \mathrm{C}$ dan lebih dari $32{ }^{\circ} \mathrm{C}$ akan menghasilkan buah cabai yang kurang baik. Pertumbuhan akan terhambat jika suhu harian di areal budidaya terlalu dingin. (Tjahjadi, 1991) mengatakan bahwa tanaman cabai dapat tumbuh pada musim kemarau apabila dengan pengairan yang cukup dan teratur.

a. Sinar Matahari

Penyinaran yang dibutuhkan adalah penyinaran secara penuh, bila penyinaran tidak penuh pertumbuhan tanaman tidak akan normal.

b. Kebutuhan air

Walaupun tanaman cabai tumbuh baik di musim kemarau tetapi juga memerlukan pengairan yang cukup. Adapun curah hujan yang dikehendaki yaitu 800-2000 mm/tahun.

c. Angin

Angin yang cocok untuk tanaman cabai adalah angin sepoi-sepoi, angin berfungsi menyediakan gas $\mathrm{CO}_{2}$ yang dibutuhkannya.

Pada penelitian ini dilakukan pada pekarangan rumah dengan rangkaian plastik UV, agar kondisi lingkungan tanaman cabai saat melakukan kegiatan dapat diatur dari sinar matahari, cuaca, kelembaban udara, dan tiupan angin dan dapat asupan air dengan menggunakan sistem fertigasi. Pada cuaca normal sinar matari yang masuk, dan menyinari tanaman cabai yaitu mulai dari jam 8 hingga 4 sore, diduga pada penelitian ini sinar matahari yang kurang dapat berpengaruh pada pertumbuhan tanaman cabai, kurang nya pertumbuhan daun akan berdampak pada proses fotositesis tanaman, dan sebagai reaksinya adalah $6 \mathrm{H}_{2} \mathrm{O}+6 \mathrm{CO}_{2}+$ cahaya $\rightarrow$ $\mathrm{C}_{6} \mathrm{H}_{12} \mathrm{O}_{6}$ (glukosa) $+6 \mathrm{O}_{2}$, Pada penelitian yang dilakukan pada bulan april hingga 
bulan juli kondisi cuaca memiliki intensitas curah hujan yang tinggi hal tersebut diduga menjadi faktor sulitnya pertumbuhan cabai.

Adapun pengaruh dari hama, pada penelitian yang dilakukan, hal ini tidak terlalu dominan fakta dilapangan tidak menunjukkan gangguan hama yang menyerang pada tanaman ini dapat disebabkan oleh kondisi buatan yaitu instalasi panel UV atau plastik UV yang menyerupai green house sehingga serangan dari hama dapat diminimalkan.

\section{KESIMPULAN}

Berdasarkan hasil penelitian yang dilakukan didapatkan kesimpulan hasil terbaik dalam pemberian konsentrasi pupuk limbah ikan pada tinggi tanaman cabai dengan sistem fertigasi adalah $5 \mathrm{ml} /$ liter dan jumlah daun tanaman adalah $10 \mathrm{ml} /$ liter. Adapun data yang didapatkan tidak signifikan atau tidak berpengaruh nyata pada pertumbuhan tinggi dan jumlah daun tanaman cabai (Capsicum annum $\mathrm{L}$ ).

\section{DAFTAR PUSTAKA}

Achmad Syaifudin, Leny Mulyani, Mukhlas Ariesta. A. (2010). "Pupuk Kosarmas" Sebagai Upaya Revitalisasi Lahan Kritis Guna Meningkatkan Kualitas Dan Kuantitas Hasil Pertanian. "Pupuk Kosarmas" Sebagai Upaya Revitalisasi Lahan Kritis Guna Meningkatkan Kualitas Dan Kuantitas Hasil Pertanian, 1-11.

Anatomi, B., \& Parman, S. (2007). Pengarub Pemberian Pupuk Organik Cair terhadap Pertumbuban dan Produksi Kentang (Solanum tuberosum L.). 15(2): 21-31. https://doi.org/10.14710/baf.v15i2.2569.

Hanisar, W., \& Bahrum, A. (2015). Pengaruh Pemberian Pupuk Organik Cair Terhadap Pertumbuhan Dan Hasil Beberapa Varietas Kacang Hijau (Vigna radiata L.). Jurnal Wan Hanisar, 1-10. Retrieved from http://repository.upy.ac.id/id/eprint/122.

Hapsari, N., \& Welasih, T. 2015. Pemanfaatan limbah ikan menjadi pupuk organik. Jurnal Teknik Lingkungan. 1(1):1-6.

Indrawati, R., Indradewa, D., Nuryani, S., \& Utami, H. (2012). Pengaruh Komposisi Media dan Kadar Nutrisi Hidroponik terhadap Pertumbuhan dan Hasil Tomat (Lycopersicon esculentum Mill.). Pengaruh Komposisi Media Dan Kadar Nutrisi Hidroponik. Terbadap Pertumbuban Dan Hasil Tomat (Lycopersicon Esculentum Mill.). 1(3):109-119. https://doi.org/10.22146/veg.1361.

Kota-mlc, T. (2019). Belajar \& diskusi tani kota-mlc \#09. (September).

Kusuma, A. (2003). Morfologi Tanaman Cabai (Capsicum annum). (1):6-8. https://doi.org/10.16309/j.cnki.issn.1007-1776.2003.03.004.

Pendapatan, A., Tani, U., Pascapanen, P., \& Merah, C. (2016). Analisis Pendapatan Usaha Tani dan Penanganan Pascapanen Cabai Merah. Jurnal Penelitian Dan 
Pengembangan

Pertanian.

$30(2): 66-72$.

https://doi.org/10.21082/jp3.v30n2.2011.p66-72.

Ridwan, D. (2013). Model of Drip Irrigation Network with Local Material Based for

Agricultural Small Land. Jurnal Irigasi. 8(2):90.

https://doi.org/10.31028/ii.v8.i2.90-98.

Rienzani Supriadi, D., D. Susila, A., \& Sulistyono, E. (2018). Penetapan Kebutuhan Air Tanaman Cabai Merah (Capsicum annuum L.) dan Cabai Rawit (Capsicum frutescens L.). Jurnal Hortikultura Indonesia. 9(1):38-46. https://doi.org/10.29244/jhi.9.1.38-46

Susilawati, Suwignyo, R. A., Munandar, \& Hasmeda, M. (2012). Irigasi Tetes pada Budidaya Cabai. Jurnal Agronomi Indonesia, 40(3):196-203.

Yasin, S. M. (2016). Respon Pertumbuhan Padi (Oryza Sativa L.) Pada Berbagai Konsentrasi Pupuk Organik Cair Daun Gamal. Jurnal Galung Tropika. 5(1):20_ 27.

Zahroh, F., Kusrinah, \& Setyawati, S. M. (2018). Perbandingan Variasi Konsentrasi Pupuk Organik Cair dari Limbah Ikan terhadap Pertumbuhan Tanaman Cabai Merah. Journal of Biology and Applied Biology Al-Hayat. 1(1):50-57. https://doi.org/10.21580/ah.v1i1.2687 